\title{
sciendo
}

CIVIL AND ENVIRONMENTAL ENGINEERING REPORTS

E-ISSN 2450-8594

CEER 2021; 31 (2): 0043-0062

DOI: 10.2478/ceer-2021-0019

Original Research Article

\section{RECENT TENDENCIES IN WASTE-BASED AGGREGATES IN CONCRETE PRODUCTION}

\author{
Marta THOMAS ${ }^{1}$ \\ Poznań University of Technology, Poznań, Poland
}

\begin{abstract}
The development of construction and the growing popularity of concrete as a building material cause a continuous increase in the demand for non-renewable raw material such as aggregate. This paper aims to analyse the possibility of using various alternative aggregates for the production of concrete. In the first part of article a detailed analysis of the European aggregate production has thus been carried out and the requirements for concrete aggregates according to European Standards have been also presented. One of the goals of sustainable waste management is to reduce landfills by finding new ways to reuse and disposing waste. Therefore in the second part of article the waste-based aggregates have been analysed. Moreover, various types of alternative aggregates such as recycled and manufactured aggregates are discussed in detail. The article presents also the properties of selected alternative aggregates with a proposal of pre-treatment. Based on the presented analyses it can be concluded that each new waste that is sourced as aggregate in concrete should undergo detailed testing because of the different chemical and mechanical properties of various waste aggregates. Hence, specific research for each waste should be undertaken.
\end{abstract}

Keywords: concrete aggregate, recycled aggregate, manufactured aggregate, alternative aggregate, concrete, aggregate

\footnotetext{
${ }^{1}$ Corresponding author: Poznań University of Technology, 60-965 Poznań, ul. Piotrowo 5, marta.thomas@put.poznan.pl, tel. +48616652165
} 


\section{INTRODUCTION}

Due to the continuous growth of the population and the development of industry, the construction industry is also developing dynamically. One of the most popular construction materials is concrete, the oldest traces of concrete dating back to 7000 B.C. Concrete started to be widely used as a construction material, in the similar form as we know nowadays, in the 1st century B.C [30]. However, the development of concrete structures gained significant pace with the discovery of reinforced concrete in 19th century. Application of reinforcement was a breakthrough and allowed concrete use not only for structures working in compression, but for structures also working in bending. Monier, in 1867, in France, patented the technology of manufacturing reinforced concrete baskets, while in the UK, Joseph-Louis Lambot as early as 1851 patented material consisting of a cement mortar reinforced with wire mesh [30]. The next step in concrete evolution was the invention of prestressed concrete, which give even wider possibilities to using concrete as a building material. In addition, the invention of post-tensioned concrete contributed to the rapid development of prefabrication. Newer and newer ways of using concrete as a building material or component of building materials increase the demand for products such as aggregates and cement. Cement is a hydraulic mineral binder whose production process generates significant amounts of $\mathrm{CO}_{2}$. Global cement production has increased 8 times in the last 50 years and has achieved level of $4000 \mathrm{Mt}$ per year in 2020, the growth of cement production from 1930s to 2020s is shown on the Fig. 1.

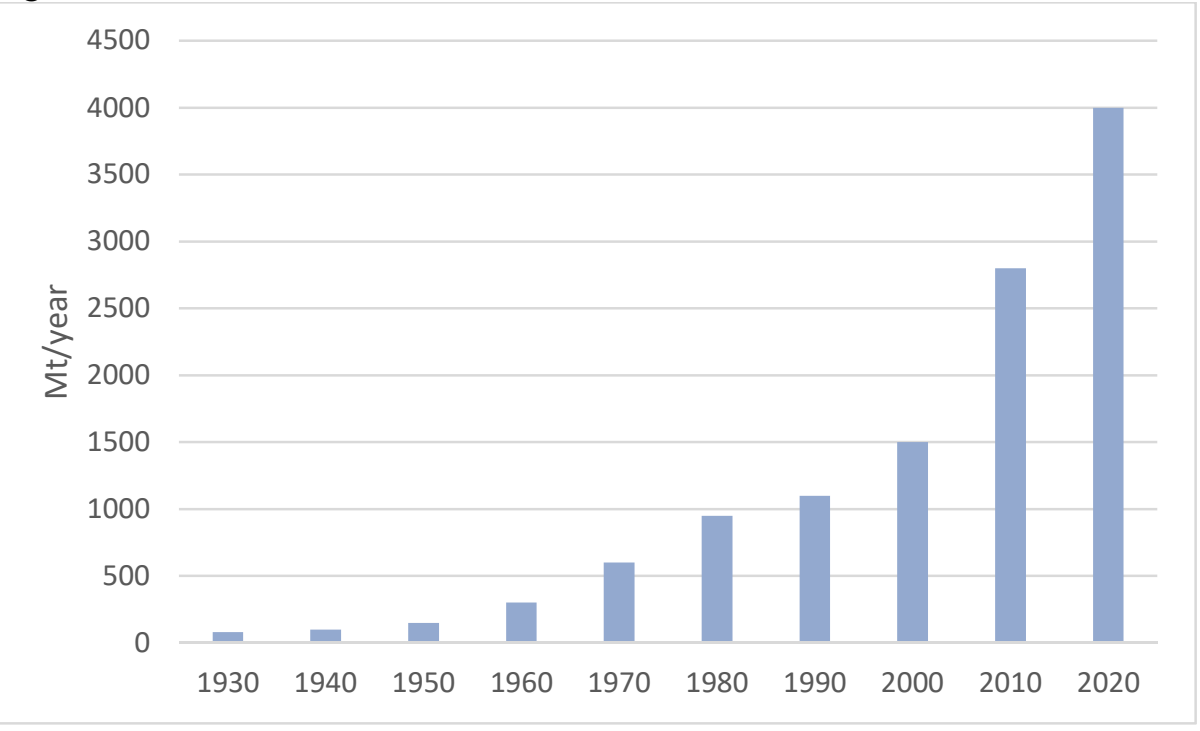


Fig. 1. Global cement production 1930 - 2018 [based on 31]

As cement production increased, $\mathrm{CO}_{2}$ emission from cement production also has risen. Fig. 2 shows how $\mathrm{CO}_{2}$ emission from cement production has increased in the last century.

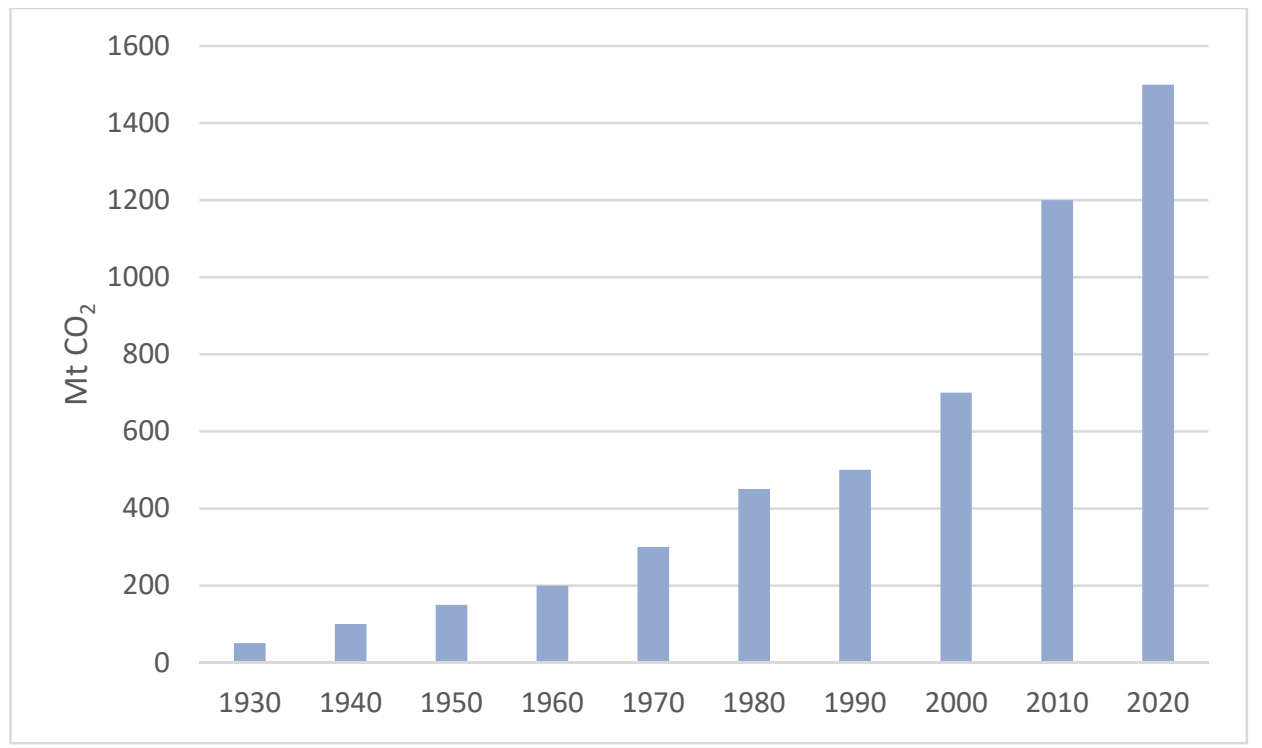

Fig. 2. Global process emissions from cement production [based on 31]

In the years 1930-1990, $\mathrm{CO}_{2}$ emission doubled every 20 years or so. However, the largest jump in $\mathrm{CO}_{2}$ value was recorded between 2000 and 2010 and was approximately $500 \mathrm{Mt}$ of $\mathrm{CO}_{2}$ annually. It is estimated that cement production is responsible for as much as $8 \%$ of total global $\mathrm{CO}_{2}$ emissions [31].

Aggregates form the second essential ingredient of concrete, and constitute $75 \%$ of the total volume of concrete. Natural aggregates (NA) are non-renewable, their stock is constantly decreasing. Increasing demand for aggregates and the fact that their deposits are exhausted, have led to the development of research into replacing natural aggregates with alternative aggregates. The aggregate deficit coincides with an increasing waste production. There is not enough space for waste disposal, municipal solid waste, as well as construction and demolition waste [37]. For this reason, the idea of using broadly understood solid waste as aggregate for concrete production solves both the problem of aggregate deficit and excessive waste production. The first attempts to reuse demolition waste were made in the 1980s by the Federal Quality Association for Recycled Building Materials, which brought together the main German recycling companies. Currently, European aggregates producers are allied under the banner of the 
"Union Europeenne des Producteurs de Granulats" (UEPG) which was established in 1987, and works for the sustainable production of aggregates.

Alternative aggregates are divided into recycled aggregates and manufactured aggregates. The division of alternative aggregates depends on their origin (Fig. 3).

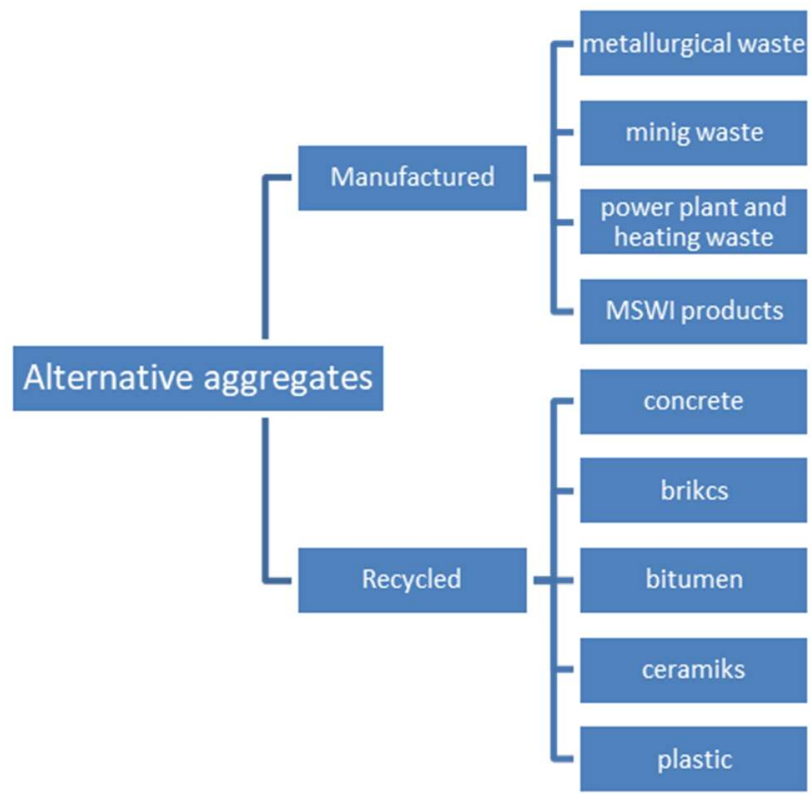

Fig. 3. The division of alternative aggregates depending on their origin [26]

Aggregates resulting from the processing of inorganic or minerals previously used in construction are called recycled aggregates [14]. Manufactured aggregates [14] are aggregates of mineral origin resulting from an industrial process involving thermal or other modification. These are also used as alternative aggregates. Metallurgical wastes such as blast furnace slag, power plant waste or mining waste are examples of manufactured aggregates. Other sources of manufactured aggregate are municipal solid waste incineration (MSWI) products such as bottom ash, fly ash and air-pollution control residues.

\section{EUROPEAN DEMAND FOR AGGREGATES}

The Grand View Research (GVR) reports that $60 \%$ of the aggregates produced in the world are used for the production of concrete, and $20 \%$ for road substructures [1]. From the European perspective, UEPG reports on European production of aggregates such as sand, gravel, crushed rock, marine, manufactured and recycled (Fig. 4) [41]. 


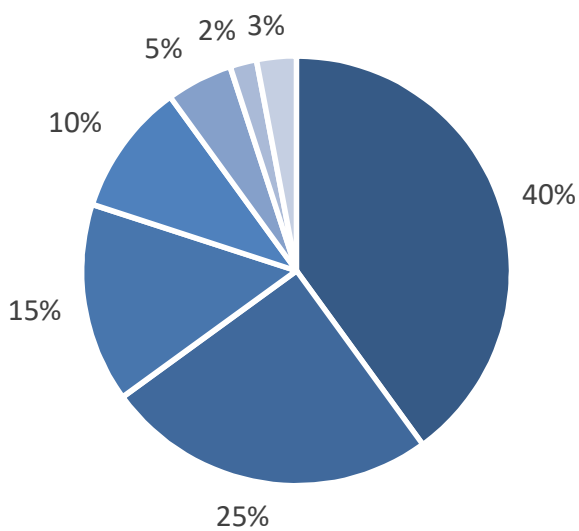

\author{
- Structural (Unbound) \\ Materials \\ - Ready Mixed Concrete \\ - Precast Concrete \\ - Asphalt Products \\ - Architectural Concrete \\ Products \\ - Railway Ballast \\ - Armour Stone
}

Fig. 4. The percentage use of aggregates as reported by UEPG [41]

Most (45\%) aggregates are used in the production of concrete in the following forms: ready mixed concrete $(25 \%)$, precast concrete $(15 \%)$ and architectural concrete products $(5 \%)$. A high amount (40\%) of aggregates are also allotted for structural (unbonded) materials production [41].

The demand for aggregates increases by about $2.3 \%$ each year, and is forecasted to reach 47.5 billion tons per year in 2023. Archival data holds that in the period from 2007 to 2014, the demand for aggregates doubled from 21 billion tons per year to close 40 billion tons per year [2]. Indeed, the Freedonia Group [17] reports that in 2010-2015, China alone generated half of the world's demand for aggregates. According to the latest data of European Aggregates Association [41] the average European aggregate demand is 6 tons per person per year. The European aggregate production in the last 11 years is shown in Fig. 5. 


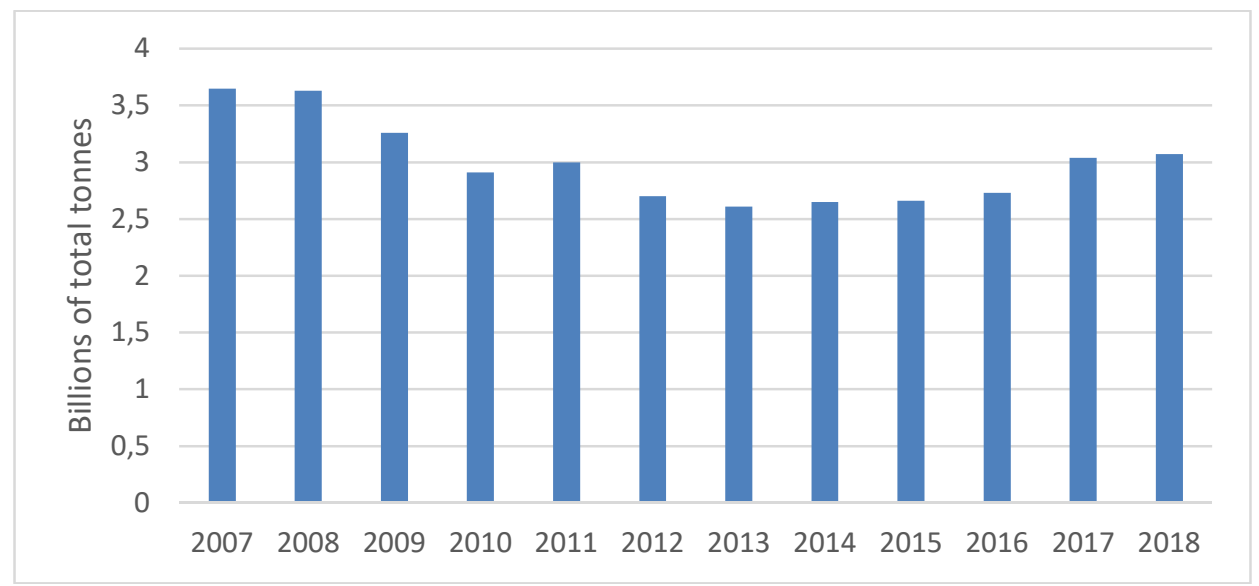

Fig. 5. Trend in production of aggregates in EU+EFTA [41]

The averaged 10-year production of aggregate in Europe is around 3 billion tons per year, as, after a slight decline in 2008 to 2013, production increased from 2014 to the level of 3 billion tons per year in 2018. Still, percentage share of types of aggregate has not change significantly over the last 10 years. Percentage share of aggregate types produced in 2018 in Europe is presented in Fig. 6.

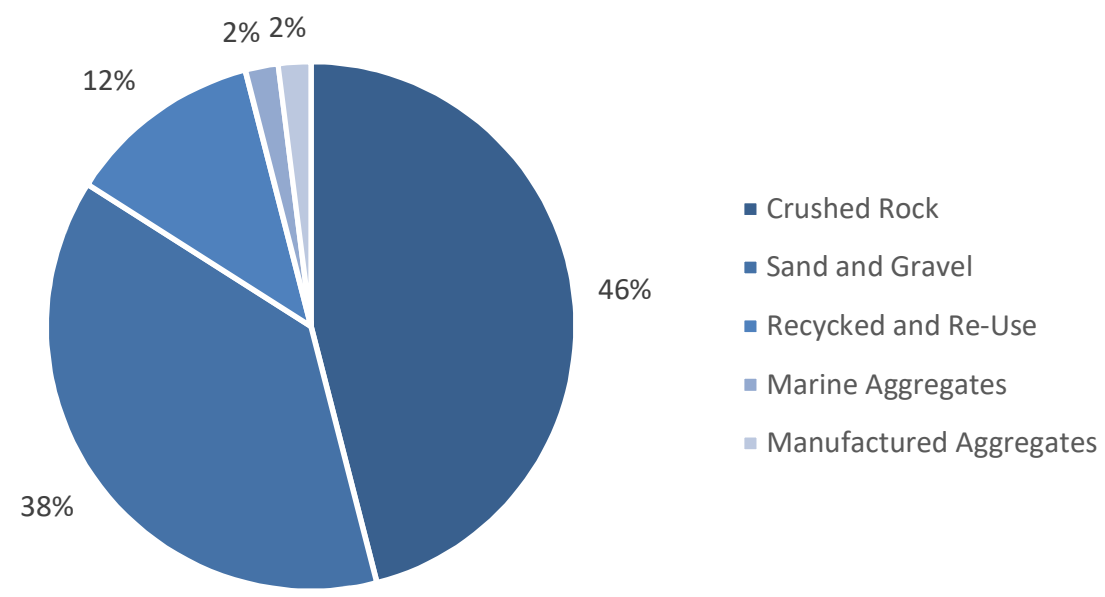

Fig. 6. Percentage share of types of aggregate in European production [41]

Crushed rock has the greatest share (46\%) in European aggregate production in 2018 , sand and gravel are in second place with $38 \%$ of share. In total, natural aggregates constitute over $80 \%$ of all aggregates in European production. 
Recycled and Re-use aggregates, in contrast, have the share on the level of $12 \%$, while Marine and Manufactured aggregates only have a 2\% share each. Provisional estimate of aggregate production for chosen European countries in 2018 is shown in Fig. 7. The largest European producers of aggregates are: Germany (597 million tons), France (429 million tons), Poland (320 million tons), UK (276 million tons), Italy (164 million tons), Spain (124 million tons), Norway (124 million tons), Austria (103 million tons) and Sweden (98 million tons). It can be noticed that four of the largest aggregate producers are responsible for the production of more than half (53\%) of the aggregates in Europe.

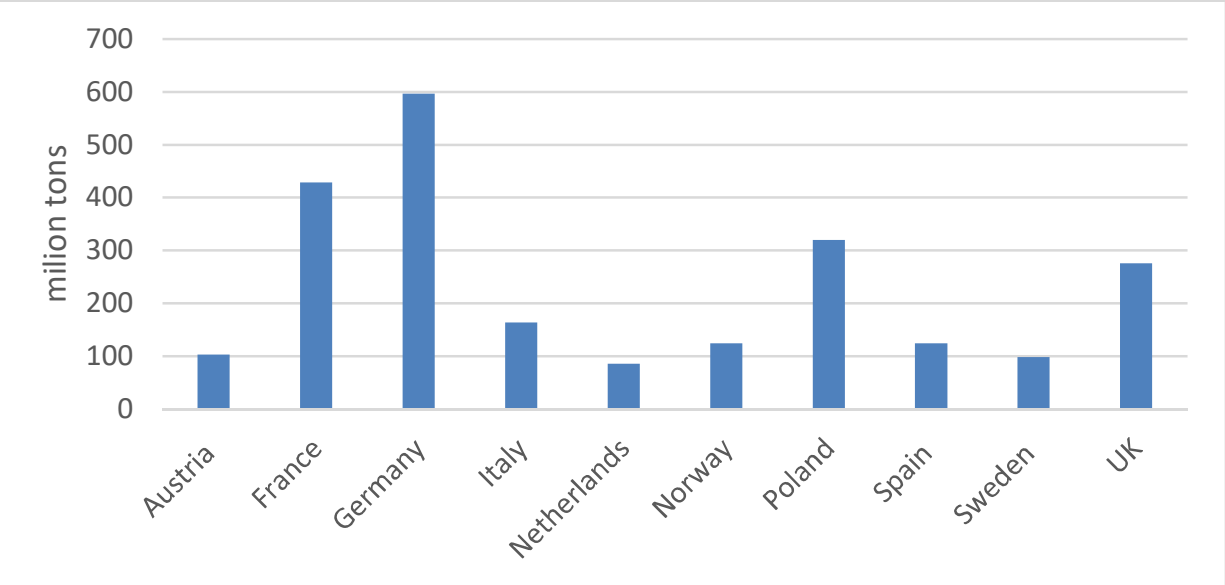

Fig. 7. Provisional Estimates of Aggregates Production Data for 2018 for chosen European countries [41]

The course of the European production of recycled and manufactured aggregates over the last 10 years is shown in Fig. 8. In recent years, an increase in the production of recycled aggregate is observable (an increase of $75 \%$ in the last 2 years alone). Still, the production of manufactured aggregates remains at a constant level of about 60 million tons per year. 


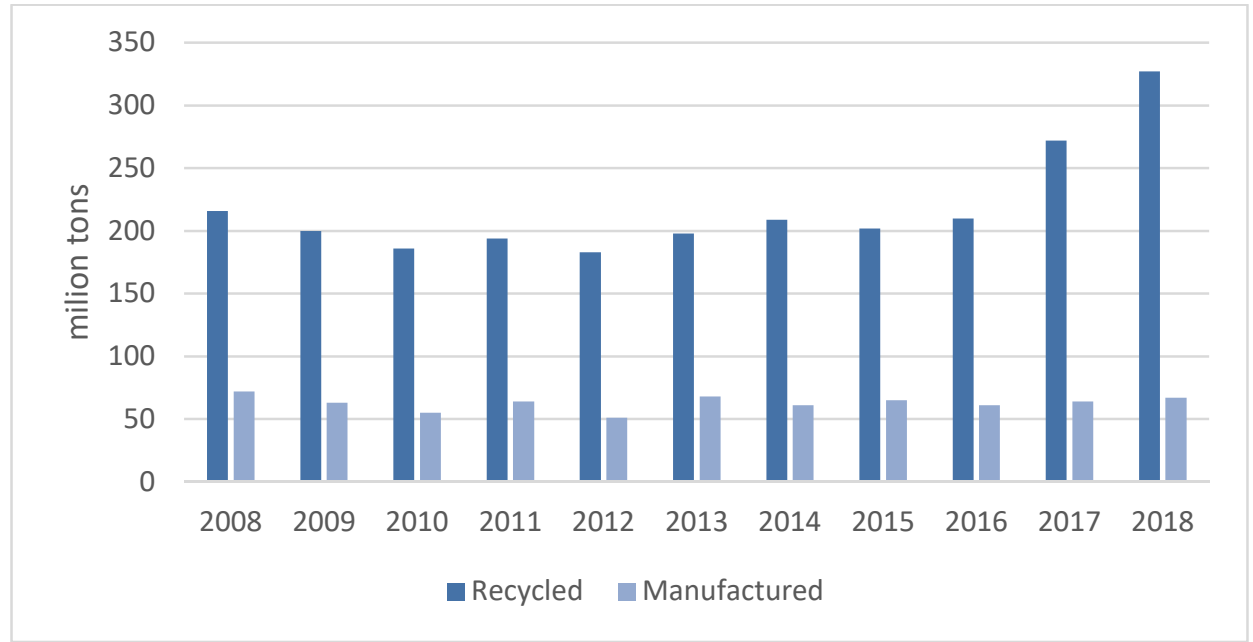

Fig. 8. Production of recycled and manufactured aggregates in EU+EFTA - 2008-2018 [41-43]

The production of recycled aggregates of chosen European countries is shown in Fig. 9. In Europe, the highest amounts of recycled aggregates are produced in France (111.8 million tons), Germany (72 million tons) and the United Kingdom (64.8 million tons). The Netherlands, Poland and Belgium also deserve mention as producers of recycled aggregate [41].

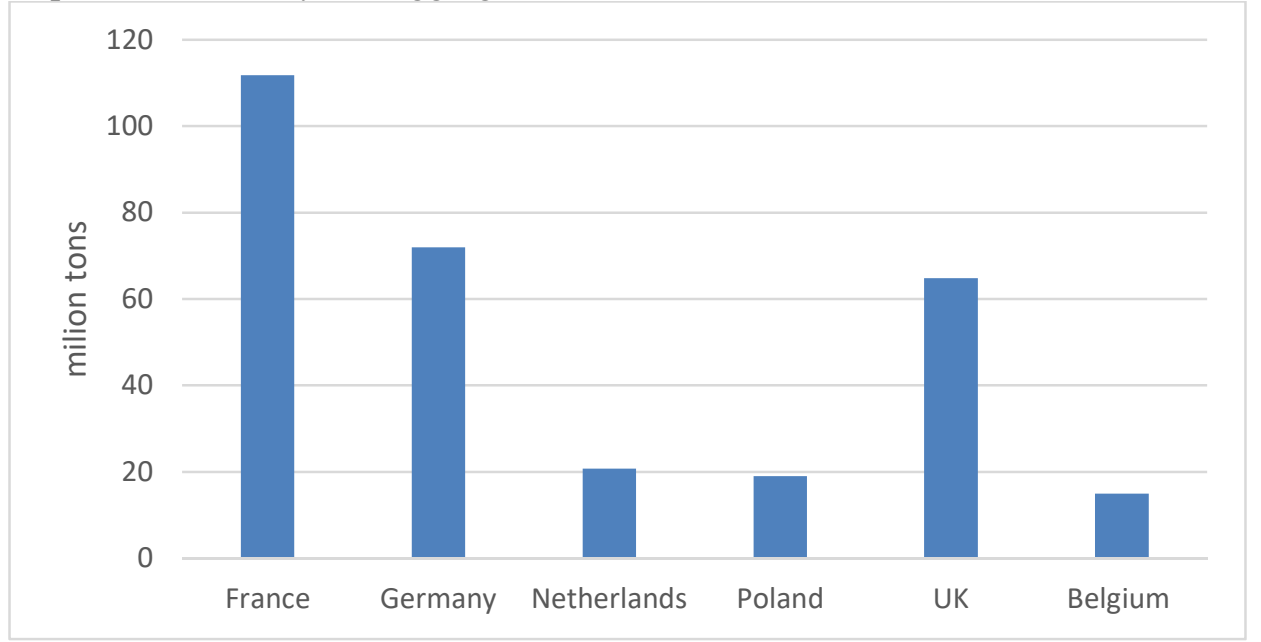

Fig. 9. Production of recycled aggregates in 2018 for chosen European countries [41]

The production of manufactured aggregates of chosen European countries is shown in Fig. 10. The largest amount of manufactured aggregate is produced in Germany (30 million tons), but Poland (10 million tons), the UK (7.4 million tons) 
and Italy (6 million tons) can be listed as significant producers of manufactured aggregates in Europe as well [41].

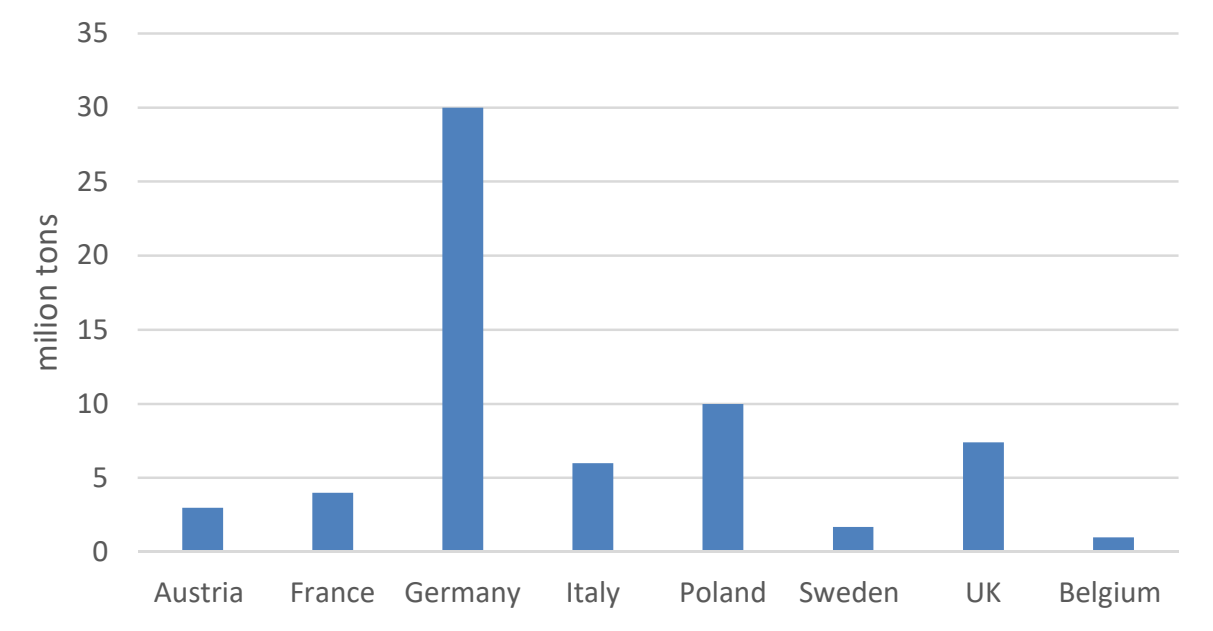

Fig. 10. Production of manufactured aggregates in 2018 for chosen European countries [41]

Share of recycled aggregate and manufactured aggregate in the total production of aggregates for given countries is shown in Fig. 11.

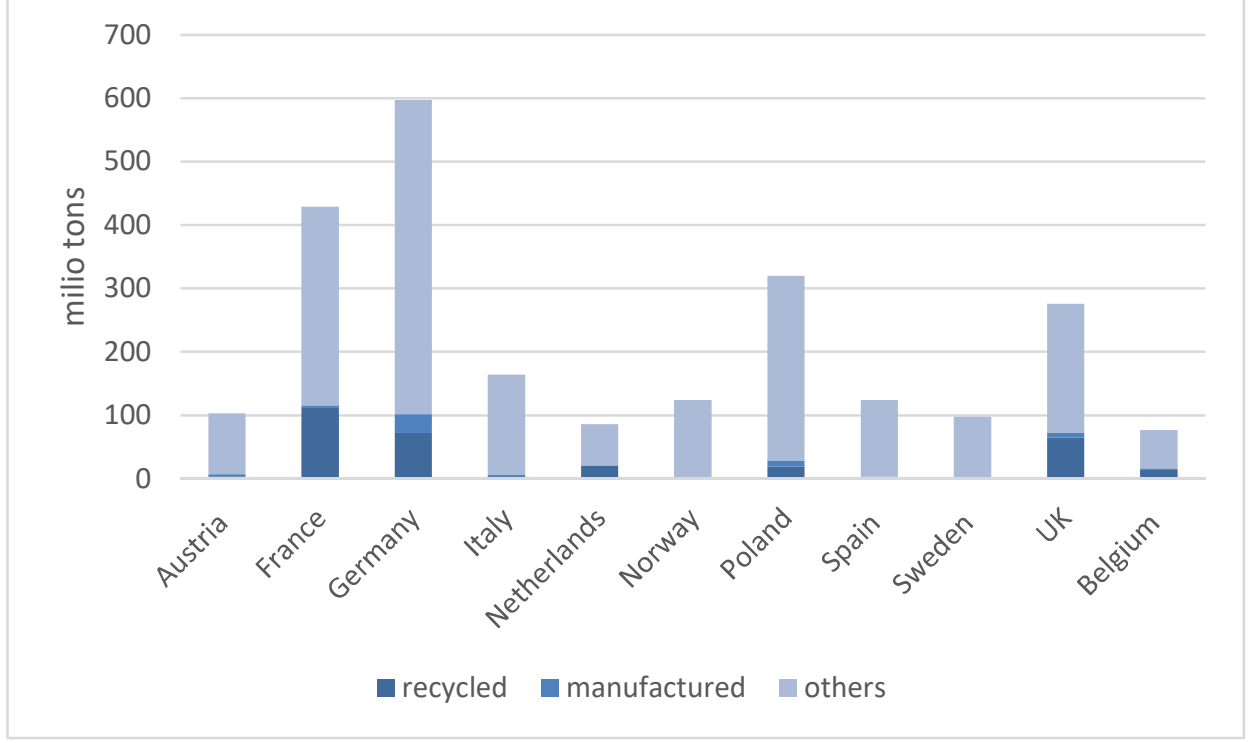

Fig. 11. Share of recycled and manufactured aggregates in the total aggregate production, in 2018, for chosen European countries [41] 
In France, Netherlands, UK and Belgium, the percentage share of recycled aggregates is the highest, at $26 \%, 24 \%, 23.5 \%$ and $19,5 \%$, respectively. The highest shares of manufactured aggregates are held by Germany (5\%), Italy (3.7\%), Poland (3.1\%), Austria (2.9\%) and the UK (2.7\%). According to UEPG, the percentage share of recycled aggregates with manufactured aggregates, in comparison to total amount of aggregates produced in Europe, rose from $8.1 \%$ in 2008 [43] to $8.6 \%$ in 2014 [42] and up to $12.8 \%$ in 2018 [41], while the share of recycled aggregates rose from $6.1 \%$ in 2008 to $10.7 \%$ in 2018 . The share of manufactured aggregate remained at $2 \%$ for the entire period from 2008 to 2018 [41- 43].

The rise in recycled aggregates production was brought about by the European Directive [15], which required Member States to prepare to increase the re-use of non-hazardous construction waste by weight to a minimum of $70 \%$ by 2020 .

In 2018, point 2 of Article 11 of the same directive [15] was expanded to include requirements for re-use of municipal solid waste. Under it, EU Member States have until 2025 to prepare to increase the reuse and recycling of municipal waste so as achieve a minimum of $55 \%$ by weight of reused waste, For 2030 - the requirements are least $60 \%$, and for 2035 - at least $65 \%$ by weight.

Nowadays, the recycled and re-used level of construction and demolition waste varies for different countries - from 10 to 90\% [8]. However, analysis of Eurostat data from recent years shows significant increase in recycling, incineration and composting of waste (Fig. 12) [28]. Reusing recycled and incinerated waste extends the supply of non-renewable raw materials. One of the ways of reusing such wastes is as aggregates for concrete.

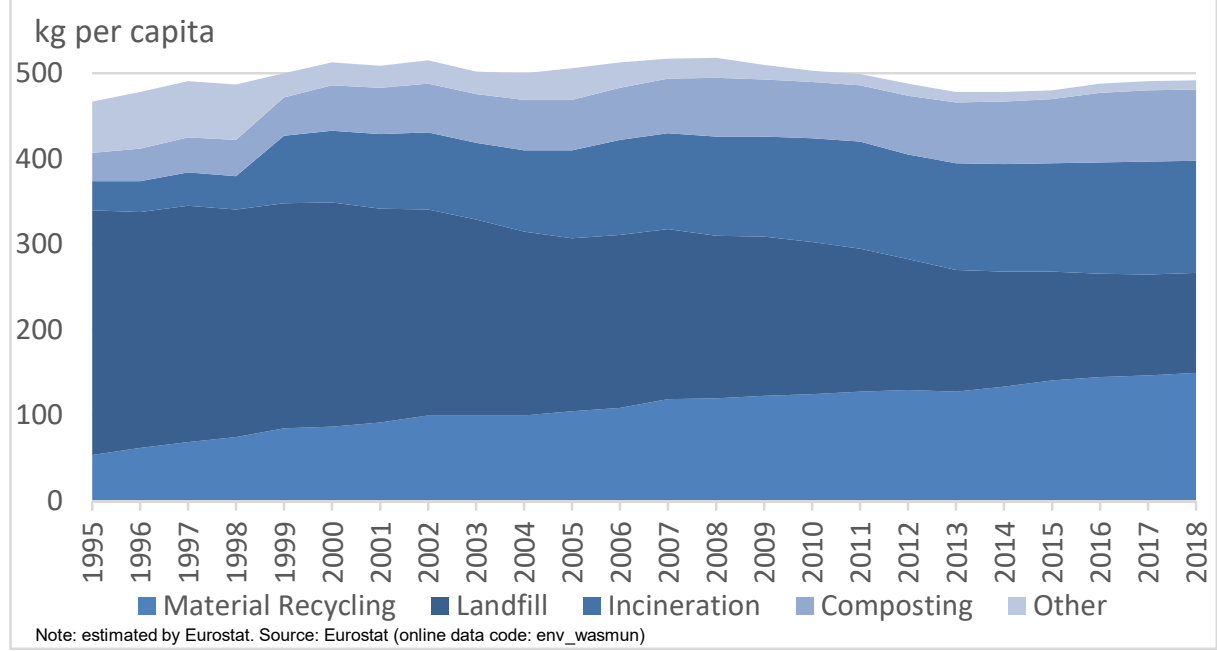

Fig. 12. Municipal waste treatment, EU-27, 1995-2017 [28] 


\section{REQUIREMENTS FOR AGGREGATES}

As already mentioned, most ( $60 \%$ of total world production) of aggregates are used to concrete production [1]. European Standards clearly defined requirements that must be meet by the aggregates destined for concrete production in the European Union [14]. The standard specifies geometric requirements such as aggregate sizes, grading, shape of coarse aggregate, shell content of coarse aggregate, fines content and their quality. In addition, physical requirements of aggregates for concrete such as resistance to fragmentation of coarse aggregate, resistance to wear of coarse aggregate, resistance to polishing and abrasion of coarse aggregate, particle density and water absorption, bulk density, durability and classification of the constituents of coarse recycled aggregates are specified by [14]. Moreover, the standard [14] sets out the chemical requirements of aggregate, including: chlorides, sulfur containing compounds and other constituents. Standard [14] also defines the evaluation of conformity, designation, marking and labelling.

\subsection{Geometric requirements}

Aggregate size is described by the $\mathrm{D} / \mathrm{d}$ ratio, which should not be less than 1.4. The grading of aggregate is determined in accordance with EN 933-1 Tests for geometrical properties of aggregates - Part 1: Determination of particle size distribution - Sieving method. Herein, the European standard distinguishes the following aggregate by grading: coarse aggregate, fine aggregate, natural graded $0 / 8 \mathrm{~mm}$ aggregate, all-in aggregate, filler aggregate and special use aggregate. The shape of coarse aggregates is assessed in terms of flakiness index as specified in EN 933-3 Tests for geometrical properties of aggregates - Part 3: Determination of particle shape - Flakiness index and in terms of shape index - as per EN 9334 Tests for geometrical properties of aggregates - Part 4: Determination of particle shape - Shape index. In contrast, shell content of coarse aggregate is determined as specified in EN 933-7 Tests for geometrical properties of aggregates - Part 7: Determination of shell content - Percentage of shells in coarse aggregate, and fine content is resolved in accordance with EN 933-1 Tests for geometrical properties of aggregates - Part 1: Determination of particle size distribution - Sieving method, while fines quality is assessed by way of annex D [14].

\subsection{Physical requirements}

Resistance to fragmentation of coarse aggregate is recognized in terms of the Los Angeles coefficient, as specified in EN 1097-2 Test for mechanical and physical properties of aggregates - Part 2: Methods for determination of resistance to fragmentation clause 5 . Resistance to wear of coarse aggregate is resolved in 
accordance with EN 1097-1 Test for mechanical and physical properties of aggregates - Part 1: Determination of the resistance to wear (micro-Deval). Resistance to polishing (polished stone value - PSV) must be in accordance with EN 1097-8 Test for mechanical and physical properties of aggregates - Part 8: Determination of the polished stone value. Resistance to surface abrasion (aggregate abrasion value - AAV) is set out in EN 1097-8 Test for mechanical and physical properties of aggregates - Part 8: Determination of the polished stone value, annex A, while resistance to abrasion from studded tyres (Nordic abrasion value-AN) is realized within EN 1097-9 Test for mechanical and physical properties of aggregates - Part 9: Determination of the resistance to wear by abrasion from studded tyres - Nordic test. The particle density and water absorption must meet the standards of EN 1097-6 Test for mechanical and physical properties of aggregates - Part 6: Determination of particle density and water absorption, while bulk density is regulated by EN 1097-3 Test for mechanical and physical properties of aggregates - Part 3: Determination of loose bulk density and voids. European Standards [14] define such types of durability as freeze/thaw resistance of coarse aggregate (specified in EN 1367 Test for thermal and weathering properties of aggregates - Part 1: Determination of resistance to freezing and thawing or EN 1367 Test for thermal and weathering properties of aggregates - Part 2: Magnesium sulfate test), Volume stability (drying shrinkage) shall not exceed 0,075\% EN 1367 Test for thermal and weathering properties of aggregates - Part 4: Determination of drying shrinkage, while alkali-silica reactivity is assessed in accordance with the provisions valid in the place of use - with the results declared. Finally, classification of the constituents of coarse recycled aggregates must comply with EN 933-11 Tests for geometrical properties of aggregates - Part 11: Classification test for the constituents of coarse recycled aggregate.

\subsection{Chemical requirements}

The water-soluble chloride ion content of aggregates for concrete must meet the standards of [13], clause 7. Acid-soluble sulfate content of the aggregates and filler aggregates for concrete are specified in [13], clause 12, while total sulfur content must comply with [13], clause 11 and shall not exceed $2 \%$ by mass for air-cooled blast-furnace slag, and not exceed $1 \%$ by mass for other aggregates. The water-soluble sulfate content of recycled aggregates is regulated through [13]. Constituents which alter the rate of setting and hardening of concrete shall be assessed for the effect on stiffening time and compressive strength and must be in accord with [13]. Air-cooled blast-furnace slag aggregate shall be free from dicalcium silicate disintegration when tested as set-out in [13] and also shall be free from iron disintegration when tested according to [13]. In addition, the carbonate content in fine aggregates for use in concrete surface courses shall be 
determined as specified in EN 196 Method of testing cement - Part 2: Chemical analysis of cement, with the test portion being prepared as regulated through [13].

\section{RECYCLING AGGRAGATES}

Recycling aggregate can be sourced from used concrete, bricks, tiles, ceramics, wood, glass, plastic, bituminous mixtures and tars, metals, soils, stones, insulation materials, gypsum based materials, waste electronic and electronical equipment, chemicals, packaging materials and hazardous substances [37]. The recycled aggregates are divided into construction and demolition waste (C\&D waste) according to their origin. Construction waste encompasses surplus materials, damage or broken materials, cut-off pieces, processing waste, used-up tools and accessories, also packing and garbage produced on the construction sites by workers. Demolition waste embraces waste from demolition of building objects, also demolition debris caused by natural disasters, civil conflicts, vandalism, explosion, fires or collapse [37]. C\&D waste accounts for around $25-30 \%$ of all waste generated in Europe [8]. Recycled aggregate was used for the first time during World War II in Germany [20]. Nowadays, using recycling aggregates is popular, due to a positive impact on the environment brought about by reducing landfill area and the extraction of natural aggregates. Furthermore, recycled aggregates are cheaper than natural. The biggest problems with recycled aggregates are its variable chemical composition and the potential content of hazardous substances. Moreover, the quality of recovered aggregate is largely dependent upon the quality of the original concrete [39]. For this reason, detailed studies of the use of individual materials as aggregates must to be carried out. Indeed, in some recycled concrete, some leaching of bromine and chromium was found [39]. Japanese researchers have also noted hexavalent-chromium and lead in concrete waste. [39] Based on on-site research, a decision about the waste pretreatment method should be made. For example, Malaysian scientists report [44] that treating plastic wastes with gamma irradiation enhances the bonding between the cement paste and the plastic aggregates, and hence, improves the matrix strength.

The most popular recycling aggregate is recycled concrete aggregate (RCA). This is created by collecting used concrete and breaking it up. The coarse recycled concrete aggregate arises from the original concrete after separation of the mortar from the aggregate rocks [27]. RCA can be used in the production of new concrete or as hydraulically bound material if the aggregate does not have hazardous contaminants. However, Vivian W.Y. Tam [37] has reported that most contaminants are usually found only on the surface layers of old concrete. What 
is more, the potentially harmful contaminants are not water-soluble so they are harmless when used as new concrete aggregate.

Research by K. McNeil and T. H.-K. Kang [27] has shown that the density of RCA is lower than the density of natural aggregate (NA). Here, some studies reported the difference in density at the level of 7-9\% [25], while others show a difference of $19 \%$ [32]. RCA also has greater water absorption and porosity than NA. Accordingly, the water absorption of RCA is equal to $4.9-5.2 \%$ and $5.6 \%$ depending on different research $[25,32]$, while NA has shown corresponding water absorption levels equal to $2.5 \%$ and $1 \%$. It should be underlined that higher water absorption negatively affects the workability of the fresh mix. Still, presaturation and water compensation during the mixing procedure are easily applied methods of obtaining appropriate workability for fresh mix based on RCA [34]. Moreover, incorporating superplasticizers also allows achieving right mix consistency [46].

The studies [32] show that the gradation curve of RCA follows the guidelines for aggregates used for concrete. However, durability of RCA is less than NA, as indicated through L.A. abrasion and crushing tests [32]. Due to the weakness of the RCA, in new concrete, most researchers recommend to replace NA only up to $30 \%$ [25], while others say that the amount depends on the exposure class of concrete, thus, recycled aggregate can be used up to $40 \%$ [7]. It should be noted, however, that higher RCA content results in poorer durability of recycled aggregate concrete (RAC) [18]. Furthermore, RCA use engenders greater shrinkage of the concrete than does NA: a mix with $100 \%$ coarse RCA has $80 \%$ greater shrinkage than a corresponding NA concrete [35].

\section{MANUFACTURED AGGRAGATES}

Manufactured aggregates are sourced from industrial process materials such as blast or electric furnace slags, china clay residues or municipal solid waste incineration processes [41].

\subsection{Metallurgical waste}

Large amounts of metallurgical waste (granulated blast furnace slag, fly ash, electric arc furnace slag, fayalite slag, basic oxygen furnace slag and copper slag) are used in the construction industry as substitutes of natural aggregates $[2,12,23,29]$ Blast furnace slag aggregates (BFSA) are obtained during the slow cooling of molten slag from blast furnace operation. The research [12] reports that BFSA can be used in high-strength concrete production up to $60 \mathrm{MPa}$. What is more, research results show that concretes with BFSA have $10 \%$ greater density than concretes with NA alone. In addition, they are characterized as having low 
water absorption and high splitting tensile strength. Concrete containing BFSA, however, exhibits higher autogenous shrinkage - the higher the replacement of NA by BFSA, the higher the shrinkage [23]. Copper slag can be also used as a sand replacement in high performance concrete production [2]. Research have shown that sand can be replaced to a maximum of $50 \%$ by copper slag without the concrete losing strength, but due to surface water absorption, which increases rapidly when replacement exceeds $40 \%$, only $40 \%$ of replacement is recommended. By-products of steelmaking such as sludge have not found a place as aggregates due to high content of heavy metals and high water demand [47], but steel slags tested [29], did meet the requirements for aggregates used in concrete production. In addition, concrete made of steel slag aggregates (SSA) exhibited satisfactory mechanical properties. SSAs were also found to be safe for reinforcement in terms of corrosion - in experiments, 90 day volume of tested samples [29] was stable. However, metallurgical wastes such as SSA are considered hazardous materials. The main problem of SSA is high zinc content, which can retard the hydration reaction.

\subsection{Municipal Solid Waste Incineration (MSWI) Products}

Recently, much research has been undertaken on re-using municipal solid waste incineration (MSWI) products such as bottom ash (BA) and fly ash (FA) [4]. MSWI products are now included, therefore, in waste management hierarchy.

Waste management hierarchy incorporates 4 steps of waste treatment: reducing mass and reusing source material, composting and recycling, recovering energy, treating raw waste material and disposing of waste product [15]. One treatment process is incineration. This can reduce the mass of waste by over $70 \%$ and volume by $90 \%$ [41]. This technology processes non-usable residual waste in such a way as to neutralize (inertize) them and use them as a source of energy. Hence, in incineration, the energy is recovered and transformed to electric and heat energy. [24] In addition, this method makes it possible to convert residues into useful raw materials. [6] Such combustion products can be used in cement and cement additive production [5], to replace cement or fine aggregate (bottom ash) in concrete [14]; in ceramics production or glass and glass-ceramics production, as a road pavement [16] or in embankments [33].

Some experimental results [10] show that replacing siliceous sand by some bottom ash aggregates leads to enhanced mechanical properties and slowingdown of water penetration. Here, MSWI products were demonstrated to have higher water absorption than natural aggregates and recycled concrete aggregates [38]. However, municipal solid waste incineration products, because of high content of heavy metals and dioxins, are treated as hazardous materials [19]. However, studies have shown that storing the slag in the open air for few months 
clearly reduces its resistance to leaching. This is due to the hydration process occurring in the grains of the slag under the influence of humidity [6].

MSWI products also have a high content of chloride and sulfate salts that can impair the durability of concrete matrixes [21]. Still, research reveals that the leaching behavior of bottom ashes is stable, only few elements (zinc, copper, antimony, chloride and sulphate) exceed the legislative limit [19,38]. Over-all, due to the high level of hazardous substances, as well as sulphates and chlorides, pretreatment of MSWI products is necessary [40].

One of the approaches to pretreatment is to treat MSWI products with water and $\mathrm{NaOH}$. This enhances their properties, and during this treatment, aluminum (Al) is converted to aluminates [5]. In addition, before phosphate-based stabilization, treatment of MSWI fly ash by $\mathrm{Na}_{2} \mathrm{CO}_{3}$ was examined [3,4,33] and various treatment ways were discovered for successfully treating different types of MSWI ash samples [40].

Another approach to pretreatment to increase the suitability of MSWI products is immobilization $[9,11,45]$. The most popular immobilization processes are geopolymerization, bituminization, vitrafication and cementation. Cementation is a very effective way of immobilizing heavy metals, as harmful substances retention can be up to $99 \%$ [22]. The C-S-H phase formed in the paste, allows immobilization through cementing [10], and immobilization comes about by means of the concrete matrix's large specific area, ability to attach other compounds to its structure and low permeability. Immobilization is preferred because it is of relatively low cost and because it affords the possibility to transform many types of waste independently of their chemical content [10]. In the concretes produced, the cement matrices should have good physical and mechanical properties so as to obtain better durability of the elements. As the properties of municipal solid waste incineration slag are similar to natural aggregates, it can replace natural aggregate partially or completely. Using MSWI slag (useless waste) instead of non-renewable natural aggregates is environment friendly and complies with the waste management hierarchy.

\section{CONCLUSION}

Sustainable management of waste and non-renewable raw materials is the main challenge of the 21 st century. The conducted analysis reveals that due to the continuous increase in demand for non-renewable raw material such as natural aggregates, and the need to reduce the production of waste going to landfills, it is necessary to look for new options for waste disposal and for obtaining alternative aggregates for concrete. Based on the analysis of the results of the mentioned studies, it can be concluded that most of the waste can be used in concrete 
production as aggregate after pre-treatment. The basic requirement that aggregate for concrete must meet are the requirements specified in the European Standard (PN-EN 12620+A1:2010). In bringing this about, the pre-treatment methods must be adapted to the initial properties of the waste and the expected properties of the concrete. Each new waste that is sourced as aggregate should undergo detailed testing because of the different chemical and mechanical properties of various waste aggregates. Hence, specific research for each waste should be undertaken. Even wastes containing harmful substances may be considered for concrete aggregate after examination of their chemical composition. This situation is made possible due to the cementation and subsequent immobilization of heavy metals. Based-on-waste concrete properties should be also checked because the durability, tightness or strength of concrete determines whether the waste remains permanently neutralized in the concrete.

It is not difficult to dispose of waste in concrete, the question is whether the immobilization of waste by cementing will be durable and environmental friendly in 5, 10 and almost the 100 upcoming years.

\section{REFERENCES}

1. Aggregates Market Size, Share Industry Research Report 2019-2025.

2. Al-Jabri, KS, Hisada, M, Al-Oraimi, SK and Al-Saidy, AH 2009. Copper slag as sand replacement for high performance concrete. Cement \& Concrete Composites 31, 483-488.

3. Aubert, JE, Husson, B and Sarramone, N 2007. Utilization of municipal solid waste incineration (MSWI) fly ash in blended cement: Part 2. Mechanical strength of mortars and environmental characteristics. Journal of Hazardous Materials 146, 12-19.

4. Aubert, JE, Husson, B and Sarramone, N 2006. Utilization of municipal solid waste incineration (MSWI) fly ash in blended cement: Part 1. Processing and characterization of MSWI fly ash, Journal of Hazardous Materials 136, 624631.

5. Bertolini, L, Carsana, M, Cassago, D, Curzio, AQ and Collepardi, M 2004. MSWI ash as mineral additions in concrete. Cement and Concrete Research 34, 1899-1906.

6. Bilitewski, B, Hardtle, G and Marek, K 2006. Waste management manualtheory and practice (polish). Warszawa: Wydawnictwo Seidel-Przywecki.

7. Concrete in accordance with DIN EN 206-1 and DIN 1045-2 with recycled aggregates in accordance with DIN EN 12620 2010, Berlin: Deutscher Ausschuss für Stahlbeton e.V. 
8. Construction and Demolition Waste, European Commission. $<$ https://ec.europa.eu/environment/waste/construction_demolition.htm> access: 18.10.2020.

9. Czerniak, A and Poszyler-Adamska, A 2006. Assessment of heavy metals immobilisation in cement-groundc omposites used for the construction of country roads. Acta Sci. Pol. Form. Circumiectus 5, 29-38.

10. Czop, M and Łaźniewska-Piekarczyk, B 2019. Evaluation of the Leachability of Contaminations of Fly and Bottom Ash from the Combustion of Solid Municipal Waste before and after Stabilization Process. Sustainability 11, 5384.

11. Czop, M, Łaźniewska-Piekarczyk, B, Piec, L, Poranek, N and Sylwa, M 2019. Impact of immobilization on the leachability of the pollutants from the concrete matrix made on the basis of concrete dust from the flue gas treatment. In Proceedings of the 19th SGEM International Multidisciplinary Scientific GeoConference EXPO Proceedings, Section Ecology and Environmental Protection, Albena, Bulgaria, 28 June-7 July 2019.

12. Demirboğa, R and Gül, R 2006. Production of high strength concrete by use of industrial by-products. Building and Environment 41, 1124-1127.

13. European Standard. EN 1744-1:2009: Tests for chemical properties of aggregates - Part 1: Chemical analysis.

14. European Standard. PN-EN 12620+A1:2010: Aggregates for concrete.

15. European Union 2018. Directive 2008/98/EC of the European Parliament and of the Council of 19 November 2008 on waste and repealing certain directives (Text with EEA relevance).

16. Foretza, R, Far, M, Segui, C and Cerda, V 2004. Characterization of bottom ash in municipal solid waste incinerators for its use in road base. Waste Management 24, 899-909.

17. Global Demands for construction aggregates to exceed 48 Billion Metric Tons in 2015. The Freedonia Group 2012.

18. Guo, $\mathrm{H}$ et al. 2018. Durability of recycled aggregate concrete e A review. Cement and Concrete Composites 89, 251-259.

19. Joseph, AM, Snellings, R, Van den Heede, P, Matthys, S and De Belie, N 2018. The Use of Municipal Solid Waste Incineration Ash in Various Building Materials: A Belgian Point of View. Materials 11, 141.

20. Khalaf, FM and DeVenny, AS 2004. Recycling of demolished masonry rubble as coarse aggregate in concrete: review. Journal of Materials in Civil Engineering 16, 331-340.

21. Król, A 2016. The effect of different exposure conditions on the characteristics of the mineral matrices stabilizing hazardous waste. Ecological Engineering 47, 143-150. 
22. Król, A 2012. Release of heavy metals from mineral composites considering environmental impact (polish) Opole: Politechnika Opolska.

23. Lee, KM, Lee, HK, Lee, SH and Kim, GY 2006. Autogenous shrinkage of concrete containing granulated blast-furnace slag. Cement and Concrete Research 36, 1279-1285.

24. Lam, CKH, Barford, JP and McKay, G 2011. Utilization of municipal solid waste incineration ash in Portland cement clinker. Clean Technologies and Environmental Policy 13, 607-615.

25. Limbachiya, MC, Leelawat, $\mathrm{T}$ and Dhir, RK 2000. Use of recycled concrete aggregate in high-strength concrete. Materials and Structures 33, 574-580.

26. Machniak, $€$ and Kozioł, W 2014. Alternative aggregates - resourece base and directions of use in construction (polish). Kruszywa: produkcja transport-zastosowanie 4, 28-33.

27. McNeil, K and Kang, THK 2013. Recycled Concrete Aggregates: A Review. International Journal of Concrete Structures and Materials 7, 61-69.

28. Municipal Waste Statistic, Eurostat. <https://ec.europa.eu/eurostat/statisticsexplained/index.php?title=Municipal_waste_statistics\#Municipal_waste_tre atment $>$ access: 18.10 .2020 .

29. Netinger, I, Bjegović, D and Vrhovac, G 2011. Utilisation of steel slag as an aggregate in concrete. Materials and Structures 44, 1565-1575.

30. Rakiewicz, W 2012. Concrete - a construction material known for centuries (polish). Przeglad budowlany 10, 13-18.

31. Robbie, $\mathrm{M}$ and Andrew, RM 2019. Global $\mathrm{CO}_{2}$ emissions from cement production, 1928-2018. Earth System Science Data 11, 1675-1710.

32. Sagoe-Crentsil, KK, Brown, T and Taylor, AH 2001. Performance of concrete made with commercially produced coarse recycled concrete aggregate. Cement and Concrete Research 31, 701-712.

33. Saikia, N et al. 2005. Pre-treatment of municipal solid waste incineration (MSWI) bottom ash for utilisation in cement mortar. Construction and Building Materials 96, 76-85.

34. Silva, RV, de Brito, J and Dhir, RK 2018. Fresh-state performance of recycled aggregate concrete: A review. Construction and Building Materials 178, 1931.

35. Silva, RV, de Brito, J and Dhir, RK 2015. Prediction of the shrinkage behavior of recycled aggregate concrete: A review. Construction and Building Materials 77, 327-339.

36. Sorlini, S, Abba, A and Colliviqnarelli, C 2011. Recovery of MSWI and soil washing residues as concrete aggregates. Waste Management 31,289-297. 
37. Tam, VWY, Soomro, M and Evangelista, ACJ 2018. A review of recycled aggregate in concrete applications (2000-2017). Construction and Building Materials 172, 272-292.

38. Tang, P, Florea, MVA, Spiesz, P and Brouwers, HJH 2015. Characteristics and application potential of municipal solid waste incineration (MSWI) bottom ashes from two waste-to-energy plants. Construction and Building Materials 83, 77-94.

39. The Cement Sustainability Initiative. Recycling Concrete: Executive summary 2009.

40. Todorovic, J and Ecke, H 2005. Treatment of MSWI residues for utilization as secondary construction minerals: a review of methods. Minerals \& Energy 20, 45-59.

41. UEPG European Aggregates Association - Annual Review (2019-2020), 2020.

42. UEPG European Aggregates Association - Annual Review (2018-2019), 2019.

43. UEPG European Aggregates Association - Annual Review (2009-2010), 2010.

44. Usman, A, Sutanto, MH and Napiah, M 2018. Effect of Recycled Plastic in Mortar and Concrete and the Application of Gamma Irradiation - A Review. International Conference on Civil and Environmental Engineering (ICCEE 2018), Kuala Lumpur, Malaysia, 65.

45. Wan, $\mathrm{S}$ at al. 2018. Hydration characteristics and modelling of ternary system of municipal solid waste incineration fly ash-blast furnace slag-cement. Construction and Building Materials 180, 154-166.

46. Yang, S 2018. Effect of Different Types of Recycled Concrete Aggregate on Equivalent Concrete Strength and Drying Shrinkage Properties. Applied Sciences 8, 2190.

47. Yellishetty, M, Karpe, V, Reddy, EH, Subhash, KN and Ranjith, PG 2008. Reuse of iron ore mineral wastes in civil engineering constructions: A case study. Resources, Conservation and Recycling 52, 1283-1289.

Editor received the manuscript: 15.12 .2020 